\title{
Resilient Water and Wastewater Infrastructure Systems through Integrated Humanitarian-Development Processes: The Case of Lebanon's Protracted Refugee Crisis
}

\author{
Amal Bakchan, ${ }^{1}$ Miriam E. Hacker, ${ }^{2}$ and Kasey M. Faust,${ }^{* 1}$ \\ ${ }^{1}$ Civil, Architectural and Environmental Engineering, The University of Texas at Austin, 301 East Dean \\ Keaton Street C1752, Austin, TX 78712, United States \\ ${ }^{2}$ Eawag, Swiss Federal Institute of Aquatic Science and Technology, Ueberlandstrasse 133, 8600 \\ Duebendorf, Switzerland \\ * corresponding author: faustk@utexas.edu
}

Number of pages: 10

Number of tables: 2

\section{CONTENTS}

1 Purpose

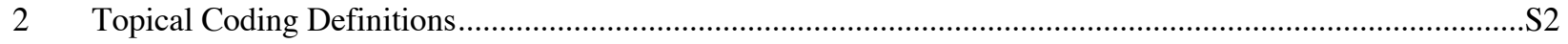

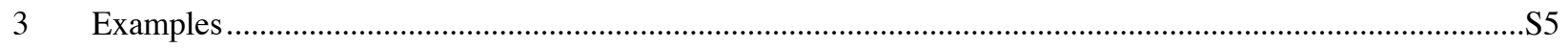

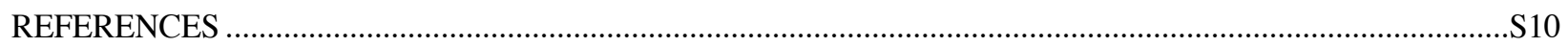




\section{Purpose}

Semi-structured interviews were conducted in Lebanon with leaders in local municipalities, including municipalities' presidents, vice presidents, and heads of construction and infrastructure, each with 5-to-20 years of experience in their respective field. These interviews were conducted between August and October 2018, focusing on Beirut and Mount Lebanon governorates.

Interviews were audio-recorded, lasting approximately 20-to-60 minutes, and were conducted in Arabic and English, depending on the participant's preference. Questions included the participants' roles and experiences in their respective organizations, the impacts of population increase on water-sector systems, and how the municipality responded to water and housing needs. Interviews ended with discussing what worked well, what might be improved, and the participant's prediction regarding their municipality's work and the overall institutional response to the crisis in the coming years.

Interview audio recordings were transcribed and uploaded into Dedoose ${ }^{1}$. This dictionary provides the definitions used for topical coding, with corresponding examples.

\section{Topical Coding DeFinitions}

The purpose of this investigation is to identify factors that contribute to the integrated processes for bridging the humanitarian-development nexus in regard to water-sector services in protracted crises. To identify these factors at the multiple abstraction levels, the two coding procedures of Grounded Theory methodopen coding and focused coding - were applied ${ }^{2-4}$. The topical coding dictionary developed for this study (Table S1) follows a similar structure of that developed in Hacker ${ }^{5}$. Table S2 provides examples corresponding to the emergent codes.

Table S1. Topical Coding Definitions

\begin{tabular}{|c|c|}
\hline Code & Definition \\
\hline \multicolumn{2}{|l|}{ Technical } \\
\hline Physical System & $\begin{array}{l}\text { Statements referencing physical structure of water-sector } \\
\text { networks; the systems' capacity; and physical access to these } \\
\text { systems }\end{array}$ \\
\hline Physical Structure & $\begin{array}{l}\text { Statements referencing physical water-sector networks within } \\
\text { a city, region, or area }\end{array}$ \\
\hline System Capacity & $\begin{array}{l}\text { Statements related to the capacity of the pre-existing water- } \\
\text { sector systems }\end{array}$ \\
\hline Physical Access & $\begin{array}{l}\text { Statements referencing access (or lack thereof) to physical } \\
\text { water-sector systems; including access to piped water } \\
\text { networks or non-piped facilities (e.g. water trucking, septic } \\
\text { tanks) }\end{array}$ \\
\hline Operations & $\begin{array}{l}\text { Statements related to the mechanism(s) for providing water- } \\
\text { sector services (e.g. providing water service for } 24 \text { hours to an } \\
\text { area then switch to another) }\end{array}$ \\
\hline
\end{tabular}


Financial

Service Payment

Statements describing the payment or non-payment for watersector services by the displaced persons

Humanitarian Financial Assistance Statements referencing financial assistance or aid provided to displaced persons, such as cash transfer

Funding

Statements referencing funds allocated for specific watersector development projects, and other finances that do not reference a specific project

Funding for Development

Statements related to funds (or lack thereof) allocated for Projects specific development projects in regard to water-sector systems (e.g. maintenance, improvements, new construction)

General Funding

Statements referencing the need for additional finances, without referencing a specific project

Social

Human-Infrastructure Interface

Statements referencing how displaced persons interact and use water-sector infrastructures, such as water consumption and use of toilets

\section{Social Relationships}

Integration

Cultural Differences

Statements describing social relations and exchanges between host and displaced persons (e.g. football game)

The statements referencing the interviewees' perceptions of displaced persons' engagement within the social structure of the host society

Statements referencing the displaced persons' social beliefs and behaviors that are different from those of the host community

Local Employment

Security

Socio-economic Status
Statements referencing opportunities within the host community to engage in local economy through work

Statements referencing the status of and efforts to ensure the physical security of host and displaced persons

Statements related to the interviewees' perceptions of displaced person's social standing or class, represented through income, financial status (e.g. poor, stable, wealth), employment status, and occupation

Institutional

Expectations of Service

Statements referencing whether or not the water-sector services should be provided to certain communities at a conceptual level 
Long-term Planning

Institutional Practices

Organizational Coordination
Statements referencing long-term structural transformation of water-sector infrastructure (e.g. improvements, new construction), at planning or ongoing development stage; and social transformation to provide social inclusion capacity for displaced persons (e.g. integration)

Statements referencing tasks and functions that municipalities perform to respond to the crisis regarding water-sector systems, such as providing awareness campaigns (e.g. infrastructure use, social); and ensuring that host community and displaced persons receive similar level of services

Statements referencing roles of and coordination (or lack thereof) between different stakeholders at the institutional level (e.g. government agencies, nonprofit organizations) for the emergency response regarding water-sector services

\begin{tabular}{|c|c|}
\hline Municipality & $\begin{array}{l}\text { Statements referencing involvement of the municipality (or } \\
\text { lack thereof) in the emergency response regarding water- } \\
\text { sector services }\end{array}$ \\
\hline Government & $\begin{array}{l}\text { Statements referencing involvement of the government (or } \\
\text { lack thereof) in the emergency response regarding water- } \\
\text { sector services }\end{array}$ \\
\hline INGO & $\begin{array}{l}\text { Statements referencing involvement of the INGO (or lack } \\
\text { thereof) in the emergency response regarding water-sector } \\
\text { services }\end{array}$ \\
\hline \multirow[t]{2}{*}{ Stakeholders' Priorities } & $\begin{array}{l}\text { Statements describing areas of emphasis by interviewees } \\
\text { towards humanitarian and development efforts for water- } \\
\text { sector systems }\end{array}$ \\
\hline & $\begin{array}{l}\text { Examples of terms/phrases used to identify "priorities" (other } \\
\text { than the term "priorities" itself) include: } \\
\text { - " “... we need to ..." } \\
\text { - "... we have to ..." } \\
\text { - "... our main focus ..." } \\
\text { - "It's important for us ..." }\end{array}$ \\
\hline
\end{tabular}




\section{EXAMPLES}

Examples are provided below in Table $\mathrm{S} 2$ as a supplement to the definitions in Table S1. Coding was completed in multiple iterations, and assessed by another researcher to verify that same codes are acknowledged. Examples assist in creating context and consistency in code applications.

Table S2. Examples of topical codes

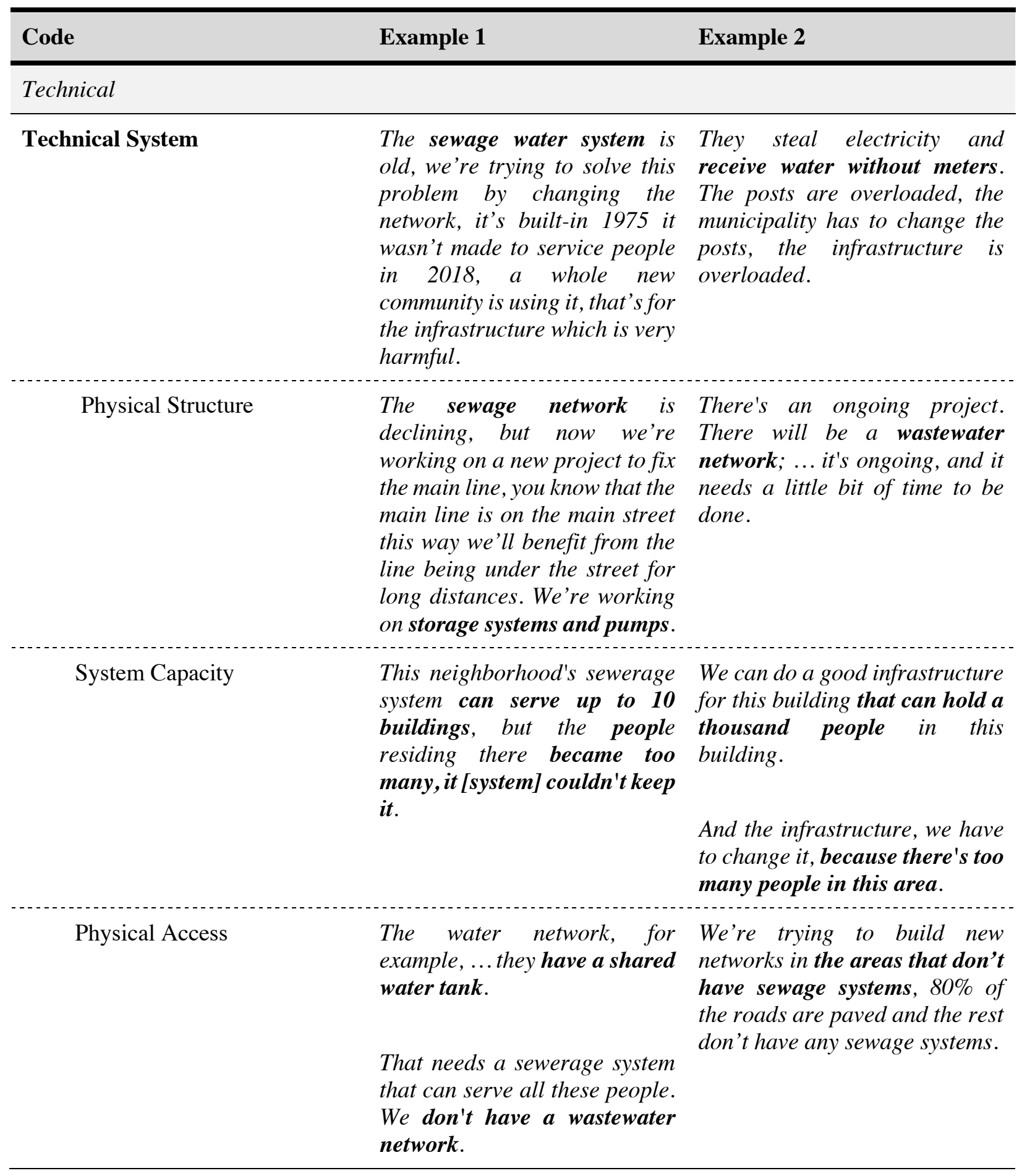




\begin{tabular}{|c|c|c|}
\hline Operations & $\begin{array}{l}\text { We started providing water for } \\
24 \text { hours in an area then we } \\
\text { switch and provide for another } \\
\text { area, and provide for a third } \\
\text { area, we regulated the } \\
\text { situation this way. }\end{array}$ & $\begin{array}{l}\text { [Capital City] has water from } \\
\text { other villages and they have } \\
\text { water 24/7, while here we get it } \\
\text { for two hours every } 15 \text { days. }\end{array}$ \\
\hline \multicolumn{3}{|l|}{ Financial } \\
\hline Service Payment & $\begin{array}{l}\text { They paid rent, but they didn't } \\
\text { pay for electricity, they didn't } \\
\text { pay for water. }\end{array}$ & $\begin{array}{l}\text { we could've taken 1,000 } \\
\text { refugees but not 4,000 in } \\
\text { addition to us, you know that } \\
\text { they don't pay [water] taxes and } \\
\text { the government isn't working to } \\
\text { solve this issue. }\end{array}$ \\
\hline $\begin{array}{l}\text { Humanitarian Financial } \\
\text { Assistance }\end{array}$ & $\begin{array}{l}\text { Most of the refugees that are in } \\
\text { our area right now, their } \\
\text { socioeconomic status has } \\
\text { become better than the } \\
\text { Lebanese's because of the help } \\
\text { and aid that they receive. }\end{array}$ & $\begin{array}{l}\text { They used to give them aid here, } \\
\text { I welcomed them in a hall here, } \\
\text { they came from all over Beirut to } \\
\text { get the financial aid. }\end{array}$ \\
\hline
\end{tabular}

\begin{tabular}{|c|c|c|}
\hline Funding & $\begin{array}{l}\text { The organizations aren't doing } \\
\text { anything for the municipality; } \\
\text { they're not giving money, } \\
\text { projects, or renovating the } \\
\text { infrastructure. }\end{array}$ & $\begin{array}{l}\text { We told them that we don't have } \\
\text { funding, they'd say that it's not } \\
\text { their problem. }\end{array}$ \\
\hline $\begin{array}{l}\text { Funding for Development } \\
\text { Projects }\end{array}$ & $\begin{array}{l}\text { They [municipalities] don't } \\
\text { have the budget to redo } \\
\text { anything, but it's mostly } \\
\text { maintenance. They've been } \\
\text { fixing whatever gets ruined; } \\
\text { because of the pressure, they } \\
\text { can't renovate the entire } \\
\text { infrastructure. }\end{array}$ & $\begin{array}{l}\text { We need financial support, if } \\
\text { that's available we can have a } \\
\text { new network, we need funds to } \\
\text { work. }\end{array}$ \\
\hline General Funding & $\begin{array}{l}\text { The main problem lays with the } \\
\text { decentralization of } \\
\text { responsibilities between the } \\
\text { government and the } \\
\text { municipality. The funds should } \\
\text { reach [us] directly because, } \\
\text { otherwise, there's a lot of } \\
\text { corruption; a lot of people take } \\
\text { from the funds for different } \\
\text { reasons. }\end{array}$ & $\begin{array}{l}\text { The main concern is getting } \\
\text { funds, whomever would be } \\
\text { ready to give them } \\
\text { [municipalities] funds. }\end{array}$ \\
\hline Social & & \\
\hline
\end{tabular}




\begin{tabular}{|c|c|c|}
\hline Human-Infrastructure Interface & $\begin{array}{l}\text { If one person uses the toilet, or } \\
\text { washes-- Now more than one } \\
\text { person uses the toilet, and the } \\
\text { way they're raised, they } \\
\text { dispose of everything in the } \\
\text { toilet and the sink, it clogs the } \\
\text { pipes, and we have to pay } \\
\text { money and fix the problem. }\end{array}$ & $\begin{array}{l}\text { About water, ... the consumption } \\
\text { was over, for that we drilled } \\
\text { three locations, and even until } \\
\text { now more than } 40 \% \text { of } \\
\text { consumption in [City Y] is going } \\
\text { to [displaced persons]. 10,000 } \\
40 \% \text { because the knowledge of } \\
\text { those people to reserve their } \\
\text { consumption is zero. }\end{array}$ \\
\hline Social Relationships & $\begin{array}{l}\text { In the beginning with the crisis } \\
\text { in Syria, the social } \\
\text { responsibility about the } \\
\text { refugees we did it in the } \\
\text { community not only in the } \\
\text { municipality, some kind of } \\
\text { special organization to take } \\
\text { care of the relationship } \\
\text { between ... refugees and the } \\
\text { government and the security } \\
\text { and we're looking to not have } \\
\text { any conflict between } \\
\text { [displaced persons] or [host } \\
\text { population] especially in } \\
\text { villages. }\end{array}$ & $\begin{array}{l}\text { There was a lot of incidents of } \\
\text { marriage between [displaced } \\
\text { persons] and [host population] } \\
\text { which caused a lot of problems. } \\
\text { We need to build better social } \\
\text { relations between them by } \\
\text { improving their living condition. }\end{array}$ \\
\hline Integration & $\begin{array}{l}\text { We can also work on things } \\
\text { that'll bring the [displaced } \\
\text { persons] and [host population] } \\
\text { together like public parks, } \\
\text { arenas, and halls; for example, } \\
\text { we had a football tournament } \\
\text { in [City X] the winner was a } \\
\text { Syrian. }\end{array}$ & $\begin{array}{l}\text { Regardless of anything, it's not } \\
\text { easy to integrate into their } \\
\text { environment and it's not easy for } \\
\text { them to integrate into ours. }\end{array}$ \\
\hline Cultural Differences & $\begin{array}{l}\text { There's a difference in culture, } \\
\text { and both communities aren't } \\
\text { going well together. }\end{array}$ & $\begin{array}{l}\text { The [displaced persons] came to } \\
\text { [this area], you know how they } \\
\text { change the society's traditions; } \\
\text {.. [they] have a different } \\
\text { culture than the people living } \\
\text { here. }\end{array}$ \\
\hline Local Employment & $\begin{array}{l}\text { The [host] people are not } \\
\text { working, while they [displaced } \\
\text { persons] are working; and they } \\
\text { are having these cards from the } \\
\text { United Nations they can get } \\
\text { food and money, and theywork, } \\
\text { also. }\end{array}$ & $\begin{array}{l}\text { There's one more thing, when } \\
\text { they came in, they worked for us } \\
\text { as construction workers or in } \\
\text { grocery shops or other types of } \\
\text { shops. }\end{array}$ \\
\hline
\end{tabular}




\begin{tabular}{|c|c|c|}
\hline Security & $\begin{array}{l}\text { The security plan is requiring } \\
\text { us to put an extra effort, we } \\
\text { need more members to keep the } \\
\text { security of the town for } \\
\text { citizens and refugees alike. } \\
\text { This takes effort. }\end{array}$ & $\begin{array}{l}\text { The most important thing for us } \\
\text { right now is security, that they } \\
\text { don't harm anyone, and no one } \\
\text { harms them. }\end{array}$ \\
\hline Socio-economic Status & $\begin{array}{l}\text { Most of the refugees that are in } \\
\text { our area right now, their } \\
\text { socioeconomic status has } \\
\text { become better than the [host } \\
\text { population]'s because of the } \\
\text { help and aid that they receive. } \\
\text { They began to rent stores, they } \\
\text { started investing. }\end{array}$ & $\begin{array}{l}\text { Some of them [displaced } \\
\text { persons] are capable of } \\
\text { investing, capable of paying } \\
\text { money, capable ofliving a better } \\
\text { lifestyle than the [host } \\
\text { population]. }\end{array}$ \\
\hline \multicolumn{3}{|l|}{ Institutional } \\
\hline \multirow[t]{2}{*}{ Expectations of Service } & $\begin{array}{l}\text { I told you that the } \\
\text { infrastructure needs work, this } \\
\text { is the main problem, for } \\
\text { example, the electricity, and } \\
\text { water; the host community's } \\
\text { needs should be provided. }\end{array}$ & $\begin{array}{l}\text { The issue was taking longer than } \\
\text { expected; schools were going to } \\
\text { open; we were trying to think of } \\
\text { a way to secure water and } \\
\text { electricity for this massive } \\
\text { number of people. }\end{array}$ \\
\hline & $\begin{array}{l}\text { They're human beings; they } \\
\text { need water, they need } \\
\text { electricity, they need sewage. }\end{array}$ & \\
\hline Long-term Planning & $\begin{array}{l}\text { There's an ongoing project. } \\
\text { There will be a wastewater } \\
\text { network, it's ongoing and it } \\
\text { needs a little bit of time to be } \\
\text { done. }\end{array}$ & $\begin{array}{l}\text { The sewage network is } \\
\text { declining, but now we're } \\
\text { working on a new project to fix } \\
\text { the main line, you know that the } \\
\text { main line is on the main street } \\
\text { this way we'll benefit from the } \\
\text { line being under the street for } \\
\text { long distances. We're working } \\
\text { on storage systems and pumps. }\end{array}$ \\
\hline Institutional Practices & $\begin{array}{l}\text { We had an agreement with the } \\
\text { [INGO X] that we can take } 500 \\
\text { refugees; they gave us } 3500 \\
\text { and said they'd help, this } \\
\text { number will surely affect us, } \\
\text { but we're trying to improve the } \\
\text { situation and they're living } \\
\text { here just like the people of the } \\
\text { town. }\end{array}$ & $\begin{array}{l}\text { The [INGO X] has helped us } \\
\text { with the rehabilitation of the } \\
\text { cultural, social Center that } \\
\text { we've built in [this area]. We } \\
\text { bring people to it and try as } \\
\text { much as we can, lecture, we try } \\
\text { as much as we can to help them, } \\
\text { we even help with teaching and } \\
\text { educating the kids and } \\
\text { disciplining, regulating them on } \\
\text { the cultural, or sports, or social }\end{array}$ \\
\hline
\end{tabular}


level. We are working as hard as we can.

\begin{tabular}{|c|c|c|}
\hline Organizational Coordination & $\begin{array}{l}\text { When dealing with the } \\
\text { organizations they should } \\
\text { approach the municipalities, } \\
\text { not the government because the } \\
\text { municipalities know more } \\
\text { about the improvements that } \\
\text { can be done. }\end{array}$ & $\begin{array}{l}\text { This has to do with the General } \\
\text { situation, and it's linked to the } \\
\text { coordination between the } \\
\text { government and the United } \\
\text { Nations, and it has to do with the } \\
\text { methodology of dealing with the } \\
\text { situation of the refugees. }\end{array}$ \\
\hline Municipality & $\begin{array}{l}\text { The issue was taking longer } \\
\text { than expected, schools were } \\
\text { going to open, we were trying } \\
\text { to think of a way to secure } \\
\text { water and electricity for this } \\
\text { massive number of people. We } \\
\text { began contacting the } \\
\text { government. }\end{array}$ & $\begin{array}{l}\text { Are we supposed to leave the } \\
\text { neighborhood without } \\
\text { electricity until the Electricity } \\
\text { Company comes? No, the } \\
\text { municipality pays and changes } \\
\text { the posts and solves the } \\
\text { problem, the same thing with } \\
\text { Water, the same thing with the } \\
\text { Sewerage system. }\end{array}$ \\
\hline
\end{tabular}

Government

We have the Health Department that comes and unclogs the sewerage when it gets clogged, they also clean river sewers. They clean it even at the beginning if winter, and at the beginning of the summer, Such project is beyond your capacity and my capacity and her capacity. This is a project that is bigger than all of that. This is a ministry-level project. There is a Ministry for the they clean the areas.

INGO Stakeholders' Priorities
[INGO X] is doing a social project, nothing to help the town, they're working on education.

In order to solve it, we need to solve the running water problem, we need to dig wells. We also have some studies about the wells we already own that aren't being maintained; we have them, the water tanks are there, but we need $\$ 50,000$ to use and maintain them.
We've taken some steps with the help of some Organizations and with the municipality's limited resources.

We also have to renovate the old network...We have water for two hours every 15 days, what can you do with it? .... It's a very big issue and it need to be handled. 


\section{REFERENCES}

1. Dedoose Version 8.3.20. Web application for managing, analyzing, and presenting qualitative and mixed method research data. Los Angeles, CA: SocioCultural Research Consultants, LLC.

www.dedoose.com. Published 2020.

2. Glaser BG. The Constant Comparative Method of Qualitative Analysis. Soc Probl. 1965;12(4):436-445.

3. Charmaz K. Constructing Grounded Theory: A Practical Guide through Qualitative Analysis. SAGE Publications Ltd; 2006.

4. Glaser BG, Strauss AL. The Discovery of Grounded Theory; Strategies for Qualitative Research. Chicago: Aldine Pub. Co.; 1967.

5. Hacker ME. Regulating Uncertainty: Institutional Implications of Regulatory Mechanisms for Temporary Accommodations for Displaced Persons in Germany and Sweden. Doctoral Thesis. 2019. 